\title{
Effects of Poor Training and Development on the Work Performance of the Fast Food Employees in Cape Town
}

\author{
Nnenna E. Ukandu \\ Faculty of Business Cape Peninsula University of Technology, Cape Town South Africa \\ Wilfred I. Ukpere \\ Department of Industrial Psychology \& People Management, Faculty of Management \\ University of Johannesburg, P. o. Box, 524, Johannesburg, South Africa \\ Corresponding email: wiukpere@uj.ac.za or wilfredisiomaukpere@gmail.com
}

Doi:10.5901/mjss.2013.v4n14p571

\section{Abstract}

This research was conducted to establish whether the fast food employees within the Cape Town metropolis were being trained, and if not, what can be the possible reason for the lack of training. Fast food employers depend on their workers' skills, knowledge and abilities for effective customer services, which make it necessary for workers to be trained and developed to achieve a better work performance. The objective of this study is to evaluate the state of training and development within the fast food outlets, in order to establish the impact of the current state of training and development on employees' work performance. The purpose is to suggest ways of improving employee job performances through training and development at fast food outlets in Cape Town. Furthermore, to encourage the management of fast food outlets in Cape Town, in order to implement training and development of workers in their workplaces as this will improve the work performance of their employees. The sample consisted of 200 employees from different fast food outlets, out of which 123 responded. A triangulation method was utilized to find information from the different units within the fast food outlets. The the managers, cashiers, production units and others form part of the sample. A closed-ended questionnaire was used. The results obtained proved that a majority of fast food employees in Cape Town do not receive enough training compared to what they should. However, some ex-staff members suggested that there is a need for employee training and development at fast food outlets to improve their job performances.

Keywords: Training, development, employee work performance, skills, job satisfaction, Workplace, fast food outlets

\section{Introduction}

Fast food is a term that is given to food that can be prepared and served quickly and easily (Chang, 2009:1). They are meals that can be prepared easily and on time. Fast foods are also foods that can be sold in a restaurant and served to customers as a packaged take-outtake-away. Fast food outlets are also known as quick service restaurants. They are operated under franchising as part of restaurant chains, which have standardized foodstuffs that are shipped to each restaurant from a central location. The capital required to open a fast food restaurant is low (Jakle \& Sculle, 1999: 1). Franchising permits a big corporation to dictate to small business persons how to operate their business at a minimize risk. The franchised system of distribution and ownership provides a powerful drive to the growth of the fast food industry in the United States (Fantasia, 1995: 208). Franchising is a way of distributing merchandise to licensed distributors.

Fast food outlets in Cape Town are in the process of making a turnaround strategy that will help to transform the organization into a more proficient, profitable and effective service organization, which will assist their customers. This transformation involves training and development programs for both new entrants and existing staff within the organization. Training is an important component of internal service quality, which is considered as a path to quality customer service, consistency in job performance and satisfaction, as well as commitment to the organization (Wesley \& Skip, 1999:176). Every worker requires rudimentary training in addition to normal induction training before they are of any value to their employers (Ball, 1992:90).

Fast food organizations have been faced with employee poor performance as a result of poor training (Wesley \& Skip, 1999: 176). Generally, researchers believe that training and development increases employee performance, job satisfaction and the length of employment of employees (Conrade \& Woods, 1994:16). Many fast food outlets in Cape 
Town have recognized the need for training and development of their employees and have taken steps to improve the quality of their training and development programs, while some are still struggling with it. Training and development at fast food outlets should constantly be updated (Chiang, Back and Canter, 2005:100).

\section{Problem Statement}

This research was conducted to evaluate the effects of training and development concerning the work performance of fast food employees in Cape Town. Training plays a major role in determining the performance of the workers and hence employees should be made capable to withstand the competitive atmosphere. If training is well planned, it can improve employees' productivity and increase the cash flow of the organization. Also, it can increase workers' job satisfaction and their commitment to their workplace. In other words training helps to improve the work performance of individual employees and within teams. It also helps to improve workers' level of motivation. The current problem is that training and development at fast food outlets seems to have been eroded as majority of the outlets do not take proper training of workers into consideration.

\section{Research Objective}

The objective of this study is to evaluate the state of training and development in the fast food outlets, in order to establish the impact of the current state on work performances. It is part of the objectives of this paper to proffer ways of improving employee job performances at fast food outlets in Cape Town, through effective training and development. Furthermore, the research is intended to encourage the management of fast food outlets in Cape Town to initiate different training and development schemes that will help to accelerate the level of motivation and employees' work performance.

\section{The Concept of Training}

Training is defined as a systematic and planned process to change the knowledge, skills and behaviour of employees to achieve organizational goals (Erasmus \& Van Dyk, 1999:2 cited in Van Dyk, Nel, Loedolff \& Haasbroek, 2001: 147). Training is also a learning experience that imposes a permanent change in an employee, which improves his/her ability to perform on the job (De Cenzo \& Robbins, 1994: 255). Training is task-oriented, which means that it focuses on the work performance of workers. Furthermore, it helps to improve employees' job performance. Training is meant to be offered when existing work standards are not impressive, and there is a lack of skills and poor attitudes of employees. This necessitates additional insight to training at fast food outlets in Cape Town as explicated in the literature below.

\section{Literature Review}

Fast food outlets, in general, cannot have a high volume of success without correctly trained and motivated staff. Due to the high degree of attrition rate in the fast food industry, the industry has a poor reputation for training. Managers seem to be reluctant to invest in training in case a staff member subsequently leaves (Lowry et al., 2002, cited in Poulston, 2008:414). Managers sometimes feel that performing a task publicly whilst having insufficient skills, jeopardizes their service quality and can demean and embarrass employees, yet training is poor or non-existent and employees are disciplined for their poor performance (Ukandu \& Ukpere, 2011, 7). However, managers in the fast food industry support training and development of employees, but do not put it into practice (Go et al., 1996).

\section{Employee Training and Development}

Training is defined as the process by which employees are provided with knowledge and skills that are required to operate within their work environment (Sommerville, 2007: 208). It is also an activity that changes workers' behaviour (Mccleland, 2002: 7). Training is an important tool in Human Resource Management practices, and hence many organizations have come to realize the importance of training and development in their workplace.

In fast food outlets in Cape Town, the competences and qualities of workers are considered as essential. The quality of services delivered depends on the quality of the employees recruited. Employee qualities also depend on how much training and development is acquired from the organization, as well as knowledge and skills gained. Employee 
training generally increases productivity, motivates workers and inspires skills by providing all the information that workers need to do their work (Yang, 2010: 15). Training and development help organizations to implement Human Resources Management practices and polices (Nickson, 2007: 154). The afore-mentioned author also states that training and development is an important development strategy for all organizations to help in improving their skills.

\section{Skills Development in the Fast Food Industry}

The nature of work and employment in the fast food industry discourages training and causes a shortage of skills in fast food outlets. According to Baum (2002:347), jobs in the fast food industry is attributed to have a tendency to low wages and skills shortage; unsocial hours; is family unfriendly, non-existence of career structures; high levels of labour turnover; and informal recruitment practices. The fast food industry, generally, is dominated by low skilled workers that are uneducated, unmotivated, untrained, unskilled and minimally productive (Shaw \& Williams, 1994:142). Again, Burns (1997:240) states that fast food industries operate within a business culture where labour is regarded as costs and skills, and are not valued or developed. He further states that fast food work provides opportunities that range from senior global business management through to work within the reach of people with a range of physical and learning disabilities, but owing to low skilled workers, these opportunities are neglected.

\section{Poor Training and Development at Fast Food Outlets}

Employee training and development helps workers to behave well with their customers (Gilbert et al.., 1998 cited in Poulston, 2008: 417). Most fast food outlets have a poor reputation for training and are unwilling to empower their workers with training in case they subsequently leave the organization (Lowry et al.., 2002: 53 \& Maxwell et al.., 2004:159). A fast food job is a job done publicly, which means that insufficient skill will place at risk the services rendered to their customers. The main argument in this article is that many fast food workers, especially in the Cape Town metropolis; do not receive enough training to enable them to do their work effectively. Inadequate training and development affects job satisfaction and work performance of workers, which, in turn, results in staff turnover and also threatens quality standards (Lashley \& Best, 2002:6). One of the biggest problems experienced in the fast food industry is a shortage of skills (HCTC, 1995; HEFCE, 1998). According to HCTF (1995), the fast food industry displays the lowest level of training. Recent research on training in the fast food industry found that only 28 per cent of this industry had a training plan, while only 19 percent had a training budget (HtF, 1996).

Additionally, training, as defined by Go et al (1996), is said to be a systematic process via which an organization's human resources gain knowledge and develop skills by instruction and practical activities that result in improved corporate performance. As stated earlier, fast food managers do not always practice training in their organizations. Many reasons have been given why they do not engage in training. According to Boella (1996), reasons for a lack of training are as follows: first, many fast food managers do not have formal training themselves and hence are not aware of training benefits. Second, employers are more interested in the operational problems of the organization rather than training and do not have time to plan ahead. Third, many fast food industries cannot afford sufficient capital to invest in training. Finally, they believe that it is the responsibility of colleges to equip their candidates with enough training. Hence, in many fast food industries, training is a theory rather than a reality (Holden, 1991 cited in Wilson, et al., 1998: 80). However, managers, instead of viewing training as an on-going process, regard it as a one-time activity that is designed to equip employees with skills to work. Fast food industries are known for poor reputation of training (Maxwell et al., 2004). Managers do not empower their employees with training in case they decide to leave. This leads to poor performance of workers. Though the workers are not trained, they are punished for poor performance. Lam and Zhang (2003) state that training and development affects employees' job satisfaction and commitment, which, in turn, affect employee retention. Furthermore, there are many ways by which the fast food employees can be trained and developed.

\section{Methods of Training}

There are different dimensions or ways of training fast food employees. A well organized training course can provide employee motivation and improve performance. The following are different types of training that might be used.

- On-the-job training - this method of training is given to both unskilled and semi-skilled employees. It can be done during working hours since employees will have to learn as they work.

- Coaching - another method that can be used in training fast food employees is via coaching. The worker can 
be trained by the supervisor or manager through use of instructional materials and guidelines.

- Understudy - this is training the employee by way of experience and observation. This will enable employees to learn by practicing the job in a real life situation.

- Job rotation - workers can be trained by rotating them from one section of the organization to another to help them know the company well, and to learn how to handle different situations in their workplace.

- Off -the- job training - employees can be sent to the organization's training centre outside their work environment to be trained.

Training results can be impressive if training is done for supervisors at least twenty five hours over ten weeks (once a week) and, in turn, these supervisors retrain their subordinates. There will be a significant improvement in employees' performance and productivity (McCormick, 1971:3 cited in Sabura, 2011:40). Training can be a failure if the program lacks a means of transferring learning to the job; if it lacks specific direction and focus and if management views it as a cost, and not an investment (Sabura, 2011: 42).

\section{Importance of Training and Development}

According to Mccleland (2002: 7), employee training and development is a crucial function of Human Resource Management and Development and helps to improve productivity and enhance employee motivation. Employees should be developed with more skills in the presence of new technologies. Employee training commands a harmonious work environment, accurate work specifications and a passion to work. It also encourages team spirit amongst workers (Trainol, 2009). It strengthens the capabilities of employees and gives them a competitive advantage. Worker's personal characters and professional abilities will be improved (Sommerville, 2007: 210). Moreover, it increases employee job satisfaction and will help them to have a better understanding of their work. Training and development enhances self development and self confidence in the workplace and also allows them to become more effective problem solvers.

For the organization, training leads to increased productivity, reduces employee accidents and safety violations, helps with organizational development, and reduces wastage and employee turnover (ibid).

\section{Research Methodology: Sample and Research Process}

The aim of this study is to derive a motivation strategy for fast food outlets in Cape Town. A case study approach was used for this research because it dealt with a specific organization, namely fast food outlets in Cape Town. The research methods that were used were both qualitative and quantitative (triangulation) as means to obtain the opinions of fast food employees concerning motivation. A total of 200 questionnaires were distributed and 123 employees responded and these were used for analysis. Furthermore, a pilot study was conducted with a few staff members and managers in the fast food industry from different outlets, while corrections were made before distributing it to others. This would allow reliability and validity. Open-ended, semi-structured interview questions were also administered face-to-face to senior and store managers of different fast food outlets to obtain their opinions of employee motivation, while a closed-ended questionnaire was distributed to other staff members. As mentioned previously, the total population that was sampled was 200. The selected sample comprised all staff members that have at least six (6) months of work experience within the fast food industry. This was to enable the researcher to obtain reliable information. A report was compiled regarding the level of motivation of workers. A high ethical standard was maintained as far as the information is concerned. In addition, the data collected was analysed and results discussed in the next section.

\section{Data Analysis}

Data analysis was conducted to determine the level of training and development practiced in the fast food industry in Cape Town. Questions were posed to employees to verify the extent of training and development at their various establishments. The following were responses that were obtained.

\section{Training and Development}

The reason for including this section was to establish if fast food workers in Cape Town are empowered by means of training and development. Training is a necessity for fast food employees because it helps the organization to achieve its goals and retain talented candidates that are suitable to work in their organization. Training and development also 
improves job performances.

\subsection{Is empowerment by means of training and development freely available in your organization?}

The rationale for the above interview question was to determine if fast food employees in Cape Town are empowered through training and development. The table below shows how the interviewees responded to the question.

Table 1:

\begin{tabular}{|cc|c|c|c|c|}
\hline & & Frequency & Percent & Valid Percent & Cumulative Percent \\
\hline Valid & Yes & 56 & 45.5 & 45.5 & 45.5 \\
& No & 67 & 54.5 & 54.5 & 100.0 \\
& Total & 123 & 100.0 & 100.0 & \\
\hline
\end{tabular}

$(n=123)$

The consolidated table above shows whether fast food employees in Cape Town are empowered by means of training and development or not. The table clearly points out that $45.5 \%$ of respondents are of the view that they are empowered by training and development, while $54.5 \%$ respondents say that they are not empowered by training and development. This table also shows that some fast food workers in Cape Town do not receive training and development, though from the percentage above, the margin between those that receive training and development and those that do not receive training and development, is not much.

Some interviewees stated that the management complained that the cost of training is high, and that they cannot afford to train all staff. Again, in the literature it was stated that staff training and development has not been effectively conducted, which has resulted in poor performances and low motivation of workers in the fast food industry. Training is important for fast food workers since it improves their work performance and results in increased employee motivation.

\subsection{How many times per year do you receive training?}

The rationale for conducting this study was to find out how many times per year fast food employees in Cape Town receive training. The respondents were meant to answer the above question. This would help the author to know if respondents had sufficient training and development opportunities in their workplace. The number of times that employees received training and development concerns their job performances.

Table 2:

\begin{tabular}{|lc|c|c|c|c|}
\hline & & Frequency & Percent & Valid Percent & Cumulative Percent \\
\hline Valid & 0 & 26 & 21.1 & 34.2 & 34.2 \\
& 1 & 35 & 28.5 & 46.1 & 80.3 \\
& 2 & 13 & 10.6 & 17.1 & 97.4 \\
& 4 & 2 & 1.6 & 2.6 & 100.0 \\
& Total & 76 & 61.8 & 100.0 & \\
Missing & System & 47 & 38.2 & & \\
Total & & 123 & 100.0 & & \\
\hline
\end{tabular}

$(n=123)$

It was shown in Table 2 that the number of times of training correlated with cumulative percentage. Zero number of times of training reflected $21.1 \%$ of employees who stated that they had no training; $28.5 \%$ of respondents said that they had training only once a year; $10.6 \%$ of respondents claim that they receive training twice a year; and $1.6 \%$ of respondents claim that they receive training 4 times a year. This result shows that the more the training, the less the percentage of responses. Employees who received training 4 times a year had the least responses. This means that fast food workers in Cape Town receive training less than 4 times a year, which is not enough to improve their performance. A total of $38.2 \%$ of respondents chose not to respond to the statement. 


\subsection{Training and development programs have improved my job performance}

The reason for asking this question was to ascertain if training and development programs have improved the performance of fast food workers in their workplace. The table below illustrates how respondents responded to the above question.

Table 3:

\begin{tabular}{|lc|c|c|c|c|}
\hline & & Frequency & Percent & Valid Percent & Cumulative Percent \\
\hline Valid & Yes & 43 & 35.0 & 38.4 & 38.4 \\
& No & 69 & 56.1 & 61.6 & 100.0 \\
& Total & 112 & 91.1 & 100.0 & \\
\multicolumn{2}{|c|}{\begin{tabular}{l} 
Missing System \\
\multicolumn{2}{|c|}{ Total }
\end{tabular}} & 11 & 8.9 & & \\
\hline
\end{tabular}

$(n=123)$

A total of $35 \%$ of respondents from the above table stated that training and development programs improved their job performance, while $56.1 \%$ claimed that training and development programs have not improved their job performance. The gap between the two percentages is quite a bit. This shows that though there is training and development in some fast food outlets, it has not improved the performance of most employees. This could be a result of the way the training was conducted or perhaps because the workers receive less training.

The number of times that the employees receive training and development has to do with their job performance and the method of training that is used. In comparison to Tables 2 and 3, it can be said that $28.5 \%$ of fast food employees in Cape Town receive training and development once in a year, while $1.6 \%$ of workers receive training and development four times a year. This shows that employees are not given enough training and development. The literature review showed that fast food employees should be trained at least once a week or for ten weeks annually. This also explains the reason why employees have poor performance. A total of $56.1 \%$ of employees accepted that training has not improved their work performance as stated above. An increase in the number of times that employees receive training and development per year increased the cumulative percentage. This shows that if the number of times of training increased per year, less people are trained. Training more fast food workers in Cape Town and introducing more hours and days of training will go a long way to improve employees' job performances.

\subsection{What is your view about the performance of your staff members?}

The managers revealed that staff performances were poor because they did not receive any formal training. They also lack self confidence and self respect. Few interviewees stated that sometimes staff performance is good and sometimes it is not. Other managers stated that workers are not motivated because there is no training given to them, while promises of recognition are made, but not delivered, and hence not enough recognition is practiced.

\section{Discussion of Results}

It is assumed here that most fast food employees are not empowered by training and development. Staff members that are empowered with training and development seem not to be effective in their work. This could be as a result of poor follow up after the training program to ensure that the new skills and knowledge acquired has actually taken place and that it is used by employees in their workplace. Results from Table 1 showed that $54.5 \%$ of respondents were not empowered with training and development, while $45.5 \%$ were empowered. The cumulative result in Table 1 also showed that $100 \%$ of respondents are not trained, while $45.5 \%$ of respondents are empowered. This shows poor training and development programs at fast food outlets in Cape Town.

The above analysis revealed that training and development of fast food workers in Cape Town is not enough. Responses from the interviews with staff and managers revealed that they are not given enough training and development, while some responded that they are not given any training at all. However, training and development is meant to improve the performance of workers. It can be said that it is not the only way whereby employees can improve their performance, but other means include improving the work environment, managerial behaviour towards workers, and communication amongst workers (Ukandu \& Ukpere, 2011: 7). This was mentioned in the main research. Also, training is 
the major tool by which employees can improve their performances. For instance, the management of fast food outlets in Cape Town can improve the performances of employees by improving their customer services skills, sales and marketing techniques, and so on. These methods can only be achieved with training and development.

Table 2 above revealed that as the amount of training and development increased, the frequency of occurrence reduced. This means that respondents received training and development less times in a year. The researcher observed from the table above that most respondents had training once a year with 35 times of occurrence, hence $28.5 \%$, while the others did not have training and development at all with 26 times of occurrence hence $21.1 \%$. The rest had training and development twice and 4 times a year. However, the number was minimal with $13 \%$ and $2 \%$, respectively.

Training plays an important role in the performance of fast food workers especially those in the Cape Town metropolis by driving customer satisfaction, and by handling their orders quicker and more accurately. It also improves employees' morale and mood and increases employees' motivation to work. Adequate training and development programs enhance the quality of employees' services. Their work environment can be frustrating and demoralizing if training and development is not given to them.

Table 3 revealed that training and development programs have not improved the performance of a majority of fast food employees in Cape Town. It also shows that $69 \%$ of respondents believe that training has not improved their job performances, while $43 \%$ of respondents stated that training and development programs have improved their job performance. There is no doubt that some fast food managers organize training and development for their staff members, but the question is: are staff members implementing the skills and knowledge that they acquire from the training program? As stated above, fast food workers are not performing well, which could be a result of poor follow up after the training programs to ensure that the new skills and knowledge that were acquired, have in fact helped and are being used by employees in their workplace. It could also be that the training and development method or technique used during the program was not successful. A majority of fast food outlets were found not to provide training and development for their workers, as shown in Table 1.

Indeed, there is a need for training and development programs at fast food outlets in Cape Town, as this will ensure better work performance and help the organization, to achieve their goals. Poor job performance can be solved by ensuring that training and development is organized for workers, and that a member of the management team attends the training and development program as well with the rest of the staff members. Again, the training objectives should be stated to staff members who attend the training program and these staff members should be followed up and their job performance monitored for a better result.

It is important to note that an increase in the number of times that training and development is offered to fast food workers in Cape Town will improve their work performance and state of motivation. Therefore, it is suggested that the number of training and development programs should be increased. Literature revealed that training should be conducted at least once a week or over a ten week period within a year. Anything less than this will be assumed as not enough for workers.

\section{Limitations}

The researcher was delayed during the data collection process as a result of the structure of the respondents' business. Fast food outlets are usually busy, hence respondents were limited with time. Also, the researcher took time to explain the questionnaires to each staff member, as most of the staff members were not properly educated and could, therefore, not read or write well. Some staff members were sick at work and could not read and so the researcher had to read and explain the questionnaire to them. Besides, some store managers and franchisees were difficult to approach as one of them did not even respond to the interview questions.

The researcher was also hindered from receiving information from some fast food outlets and some store managers warned beforehand not to bring questions from certain areas of study. Some fast food outlets did not give permission to conduct the research at their outlets, while some workers also did not respond to the questions, hence there was some missing data, which was negligible and did not affect the result.

\section{Conclusion}

It is clear from the analysis that employee training and development at fast food outlets in Cape Town was not sufficient and as a result has not improved staff performances. This was assumed to be a result of the method of training and development; poor follow up after training and the number of times per year that this training was administered. The 
management at fast food outlets in Cape Town was advised to take training and development of their employees seriously, as this can destroy or mend their employees. Training and development should certainly become part of the culture of most fast food outlets in Cape Town and employees' benefits, including other economic issues, should be emphasised. Therefore, a policy that promotes training and development of employees at fast food outlets within Cape Town should be introduced in order to improve workers' job performance. The importance of training and development is multi-fold as stated above, and includes: a harmonious work environment, accurate work specifications and a passion to work. It also encourages team spirit amongst workers. It strengthens the capabilities of employees and gives them a competitive advantage. Workers' personal characteristics and professional abilities are improved. Furthermore, it increases employee job satisfaction and helps them to have a better understanding of their work. Training and development enhances self development and self confidence in the workplace and also allows them to become more effective problem solvers. For the organization, training leads to increased productivity, reduces employee accidents and safety violations, helps in organizational development and reduces wastage and employee turnover. Finally, there should be a strategic method of training and development of workers that is introduced at fast food outlets to enhance job performance and to reduce employee turnover.

\section{Recommendations}

In order to develop the abilities of employees to satisfy their present and future needs, a strategic method of training and development should be introduced. This will ensure good execution of tasks and behavioural changes on the part of workers. It enhances the skills and abilities of workers in their job performances. However, there is a need for managements at fast food outlets to initiate a formal, systematic and holistic method of training and development of their workers to improve the skills and abilities of their workers, and increase their motivation to work. The managements at fast food outlets in Cape Town should train their workers by using on-the-job training methods. Workers should be trained within their actual work environments as a real life situation, which will help employees to learn through experience, and hence be motivated to work. Fast food workers should be trained by using job rotation in different departments of the outlets, as this will allow workers to gain detailed experience of the job and be able to work in different posts without someone helping them. Workers should be trained by inviting an experienced worker to present an oral presentation of the job (coaching). Furthermore, employees should be given instructions or a list of steps, which they can follow to perform a given task (job instruction). In addition, new employees should be placed under the auspices of an experienced person (apprenticeship), which will result in high levels of motivation amongst workers, as well as better job performance.

\section{References}

Ball, S. 1992. Fast food Operations and their Management. Leckhamton: Stanley Thomas Publishers.

Boella, M. J. 1996. Human Resource Management in the Hospitality Industry. Cheltenham: Stanley Thornes.

Chang, P. 2009. Fast Food. The British Library- Fast Food and Snacks Industry Guide. London.

Chiang, C.F., Back, K.J. and Canter, D.D. 2005. The impact of Employee Training on Job Satisfaction and Intention to stay in the Hotel Industry. Journal of Human Resources in Hospitality \& Tourism, 4 (2); 99-118.

Conrade, G. and Woods, R. N. 1994. Training in the U.S. lodging industry: Perception and reality. Cornell Hotel \& Restaurant Administration Quarterly, 35 (5); 16-21.

Fantasia, F. 1995. Fast food in France. Theory and Society, 24 (2); 201-243.

Gilbert, D., Guerrier, Y., and Guy, J. 1998. Sexual harassment issues in the hospitality industry. International Journal of Contemporary Hospitality Management, 10 (2); 48-53.

Go, F.M., Monachello, M.L., Baum, T. 1996. Human Resource Management in the Hospitality Industry. New York: John Wiley \& Sons.

HCTC 1995. Training - Who needs it? Hotel and catering training company, London.

HEFCE 1998. Review of Hospitality Management, London.

HtF 1996. Catering and hospitality Industry: Key facts and figures Research Report, Hospitality Training Foundation, London.

Jakle, J. A. and Sculle, K.A. 1999. Fast food: Roadside Restaurants in the Automobile Age: The road and American Culture. Baltimore: John Hopkins University Press.

Lashley, C. and Best, W. 2002. Employee Induction in licensed retail organizations. International Journal of Contemporary Hospitality Management, 14 (1); 6-13.

Lowry, D., Simon, A., and Kimberley, N. 2002. Toward improved employment relations practices of casual employees in the new South wales registered club industry. Human Resources Development Quaterly, 13 (1); 53-70.

Maxwell, G., Watson, S. and Quail, S. 2004. Quality Service in the International hotel Sector: a catalyst for strategic human resource development. Journal of European Industrial Training, 28 (2); 159-182. 
Mcclelland, S.D. 2002. A Training needs Assessment for the United Way of Dunn Cunty Wisconsin. The Graduate School, University of Wisconsin Stout.

Nickson, D. 2007. Human Resource Management. London: Thomson.

Poulston, J. 2008. Hospitality workplace problems and poor training: a close relationship. International Journal of Contemporary Hospitality Management, 20 (4); 412-427.

Sommerville, K.L. 2007. Hospitality Employee Management and Supervision, Concepts and Practical Applications. New Jersey: John Wiley \& Sons.

Trainol. 2009. The importance of Staff training. Online (Available) http://www.trainol.com/news_show.asp?news_id=877 [24 July 2011].

Ukandu, N.E. and Ukpere, W.I. 2011. The Causes of Low Employee Motivation within Cape Town's fast food industry. Cape Peninsula University of Technology, Cape Town.

Wesley, S. R. and Skip, S. 1999. Training and its impact on organizational commitment among lodging employees. Journal of Hospitality \&n Tourism Research, 23 (2); 176-194.

Yang, X. 2010. The Importance of Staff Training in the Hotel Industry. Vaasan University of Applied Sciences. Vaasan Ammattikorkeakoulu. 
